Artikel Penelitian

\title{
Sintesis Senyawa Vanilil Metil Keton dan Uji Aktivitas Antiinflamasi terhadap Enzim COX-1 dan COX-2 melalui Analisis In Silico
}

\author{
Khoirotul Ummah ${ }^{*}$, Robby Gus Mahardika², Ana Mardliyah ${ }^{3}$ \\ 1Jurusan Pendidikan Ilmu Pengetahuan Alam, Fakultas Tarbiyah dan Keguruan, Universitas Islam Negeri Sunan Ampel \\ Surabaya, Indonesia, 60237 \\ 2Jurusan Kimia, Fakultas Teknik, Universitas Bangka Belitung, Bangka Kepulauan Bangka Belitung, Indonesia, 33126 \\ 3Jurusan Kimia, Fakultas Sains dan Teknologi, Universitas Islam Negeri Walisongo, Semarang, Indonesia, 50185
}

\section{INFO ARTIKEL}

\section{Riwayat Artikel}

Diterima 7 Oktober 2020

Direvisi 30 Oktober 2020

Tersedia online 23 November 2020

*Email penulis korespondensi:
khoirotul.ummah@uinsby.ac.id

\section{ABSTRAK}

This study carries out the synthesis of vanillyl methyl ketone from eugenol through Wacker oxidation and anti-inflammatory activity test toward COX-1 and COX-2 through in silico analysis. Wacker oxidation proses were catalyzed by $\mathrm{PdCl}_{2}$ and $\mathrm{CuCl}_{2}$ using DMF solvent under the aerobic condition at room temperature for 48 hours. The synthesis product was purified by column chromatography and was characterized by NMR, IR and MS spectroscopy. By spectroscopic methods, characterization showed that vanillyl methyl ketone was formed with a yield of $45 \%$, and vanillin (3\%) was produced as a by-product. The anti-inflammatory activity of vanillyl methyl ketone was carried out by molecular docking toward COX-1 and COX-2 obtained from PDB. The analysis showed that the antiinflammatory activity and selectivity toward COX-2 of vanillyl methyl ketone was higher than eugenol. This was shown by the low binding energy affinity and the number of hydrogen bonds formed between the vanillyl methyl ketone and the enzyme's active site.

Keywords: Eugenol, Wacker oxidation, vanillyl methyl ketone, anti-inflammatory, in silico

Pada penelitian ini dilakukan sintesis senyawa vanilil metil keton dari eugenol melalui oksidasi Wacker serta dilakukan uji aktivitas antiinflamasi terhadap enzim COX-1 dan COX-2 melalui analisis in silico. Proses oksidasi Wacker dikatalisis oleh $\mathrm{PdCl}_{2}$ dan $\mathrm{CuCl}_{2}$ menggunakan pelarut DMF dalam kondisi aerob pada suhu ruang selama 48 jam. Senyawa hasil sintesis dipisahkan menggunakan kolom kromatografi dan dikarakterisasi menggunakan spektroskopi NMR, IR dan MS. Hasil karakterisasi menunjukkan bahwa senyawa vanilil metil keton telah terbentuk dengan randemen sebanyak $45 \%$ dan juga dihasilkan senyawa vanillin $(3 \%)$ sebagai produk samping. Aktivitas antiinflamasi senyawa vanilil metil keton dilakukan dengan docking molekuler terhadap enzim COX-1 dan COX-2 yang diperoleh dari PDB. Hasil analisis menunjukkan bahwa aktivitas antiinflamasi dan selektivitas terhadap COX-2 pada senyawa vanilil metil keton lebih tinggi dibandingkan eugenol. Hal ini ditunjukkan melalui rendahnya afinitas energi pengikatan dan banyaknya ikatan hidrogen yang terbentuk antara vanilil metil keton dengan sisi aktif enzim.

Kata kunci: Eugenol, oksidasi Wacker, vanilil metil keton, antiinflamasi, in silico 


\section{Pendahuluan}

Obat antiinflamasi nonsteroid (NSAID) dikenal sebagai senyawa aktif farmakologis yang digunakan dalam mengatasi peradangan, nyeri, dan demam [1]. NSAID bekerja menghambat aktivitas enzim siklooksigenase (COX-1 dan COX-2) dalam mengkatalisis pembentukan prostaglandin (mediator inflamasi) [1, 2, 3]. Enzim COX-1 secara konstitutif terdapat pada sebagian besar jaringan dan organ untuk mengkatalisis sintesis prostaglandin dalam regulasi fisiologis dan aktivitas seluler, sedangkan COX-2 distimulasi oleh sitokin, mitogen, dan endotoksin yang terinduksi pada sel inflamasi [4]. Berdasarkan mekanisme tersebut, efek antipiretik yang dihasilkan lebih efektif apabila dilakukan penghambatan terhadap enzim COX-2, sedangkan kemungkinan efek samping yang ditimbulkan akan lebih banyak terjadi pada penghambatan enzim COX-1 [5]. Secara umum obat-obat NSAID bekerja aktif dalam penghambatan aktivitas enzim COX-1 dan COX-2 $[5,6]$. Penggunaan obat-obatan NSAID dalam jangka panjang juga menyebabkan efek samping seperti peradangan lambung, peningkatan resiko jantung dan hepatotoksik [7]. Oleh karena itu, perlu dilakukan penelitian lebih lanjut tentang obat antiinflamasi yang aman dan selektif terhadap penghambatan enzim COX-2.

Penelitian antiinflamasi berbasis bahan alam telah banyak dilakukan untuk menemukan obat antiinflamasi dengan efek samping yang lebih kecil $[8,9]$. Senyawa bahan alam yang berpotensi sebagai antiinflamasi diantaranya yaitu eugenol $[10,11]$. Eugenol merupakan senyawa utama dalam minyak cengkeh (80-90\%) dan tersedia melimpah di Indonesia [12]. Selain berpotensi sebagai antiinflamasi, eugenol juga memiliki sifat farmakologi sebagai antibakteri, antioksidan, dan analgesik $[13,15]$. Struktur senyawa eugenol berupa fenil propana dengan gugus fungsi hidroksi, metoksi, dan olefin. Beberapa penelitian telah dilakukan untuk mentransformasi eugenol menjadi senyawa turunannya yang bernilai lebih tinggi seperti flavonoid, hidroksitirosol, metileugenol, dan bahan dasar polimer terbarukan [16, 17, 18, 19].

Kajian in silico terhadap senyawa-senyawa antiinflamasi menunjukkan bahwa adanya cincin aromatik pada senyawa ligan dapat meningkatkan interaksinya dengan sisi aktif enzim [20]. Selain meningkatkan aktivitas antiinflamasi, adanya gugus karbonil seperti mono keton atau diketon pada senyawa ligan dapat meningkatkan selektivitas inhibisinya terhadap COX-2 [21]. Dengan mentransformasi gugus olefin pada eugenol menjadi gugus keton diharapkan dapat meningkatkan aktivitasnya sebagai antiinflamasi. Gugus olefin dapat ditransformasi menjadi gugus keton melalui oksidasi Wacker menggunakan katalis paladium, air dan ko-oksidan [22]. Dalam reaksi oksidasi Wacker, katalis $\mathrm{Pd}$ (II) akan mengalami reduksi menjadi $\mathrm{Pd}(0)$ yang kemudian dapat dioksidasi kembali oleh ko-oksidan seperti $\mathrm{CuCl}_{2}$ [23]. Oksidasi Wacker banyak digunakan dalam berbagai sintesis senyawa organik karena dianggap sebagai reaksi yang paling efisien dan spesifik dalam mengubah olefin terminal menjadi metil keton [24]. Konversi gugus keton yang dibentuk dapat dipengaruhi oleh struktur ligan, substrat dan senyawa lain yang ikut dalam reaksi [25]. Pelarut yang digunakan selama proses oksidasi juga berperan penting dalam terbentuknya produk yang dihasilkan. Pelarut yang berpotensi sebagai nukleofil seperti metanol dan etanol dapat menggantikan molekul $\mathrm{H}_{2} \mathrm{O}$ dalam proses oksidasi Wacker sehingga menghasilkan produk yang bervariatif [26]. Berdasarkan latar belakang tersebut, maka dalam penelitian ini dilakukan transformasi gugus olefin pada eugenol menjadi senyawa vanilil metil keton dan analisis aktivitas antiinflamasi melalui docking molekuler.

\section{Bahan dan Metode}

\subsection{Bahan}

Eugenol diperoleh dari PT. Indesso Utama Kencana. Bahan kimia yang digunakan adalah $\mathrm{PdCl}_{2}$ 99\% (Sigma Aldrich), $\mathrm{CuCl}_{2}$ 99\% (Sigma Aldrich), dan gas oksigen $\left(\mathrm{O}_{2}\right)$ 95\% (Oxycan). Pelarut yang digunakan yaitu dimetil formamida (DMF) p.a (Merck), diklorometana (DCM) p.a (Merck) dan n-heksana p.a (Merck). Kromatografi lapis tipis dilakukan menggunakan plat gel silika pra-dilapisi 60 F254 (ketebalan 0,25 mm) (Merck). Kromatografi kolom flash dilakukan menggunakan silika gel 60 (70-230 mesh) (Merck) dengan pelarut n-heksana dan diklorometana yang baru didestilasi.

Pada analisis in silico, molekul enzim COX-1 dan COX-2 pada manusia diperoleh dari Protein Data Bank (PDB) https://www.rcsb.org dengan kode COX-1 (ID: 5GMM) dan COX-2 (ID: 5GMN). Ligan diperoleh dari bank data https://www.pubchem.com dengan kode vanilil metil keton (CID: 17262) dan eugenol (CID: 3314). Simulasi docking molekuler dilakukan dengan menggunakan Microsoft Surface Laptop 2 core i5 dengan Windows 10 Home. Beberapa software yang digunakan adalah Discovery Studio Client 4.1, Autodock 4.2, Autodock Vina, PyMOL dan LigPlot.

\subsection{Sintesis Senyawa Vanilil Metil Keton}

Sebanyak $1,02 \mathrm{~g}(6 \mathrm{mmol})$ senyawa eugenol dilarutkan dalam $120 \mathrm{~mL}$ dimetil formamida (DMF) dan dimasukkan dalam labu alas bulat $250 \mathrm{~mL}$. Selanjutnya, ditambahkan $12 \mathrm{~mL} \mathrm{H} \mathrm{H}_{2} ; 0,098 \mathrm{~g}(0,55 \mathrm{mmol}) \mathrm{PdCl}_{2}$ dan 0,82 $\mathrm{g} \mathrm{(6} \mathrm{mmol)}$ $\mathrm{CuCl}_{2}$ kemudian bagian atas labu ditutup dengan balon yang berisi oksigen. Campuran tersebut diaduk menggunakan 
pengaduk magnetik pada temperatur $25^{\circ} \mathrm{C}$ selama 48 jam dan proses reaksi dipantau menggunakan $\mathrm{KLT}$ dengan eluen n-heksana:diklorometana (3:7). Setelah reaktan habis, reaksi dihentikan dan diperoleh campuran produk berwarna coklat. Hasil reaksi diekstraksi menggunakan pelarut diklorometana (DCM) dan air dengan perbandingan 1:1. Selanjutnya fasa organik (DCM) diekstraksi kembali dengan akuades (1:10) untuk menghilangkan sisa DMF dari reaksi tersebut. Fasa organik dipisahkan dan dilakukan evaporasi sehingga diperoleh campuran dua senyawa hasil reaksi. Campuran tersebut dipisahkan menggunakan kolom kromatografi dengan eluen n-heksana:diklorometana (3:7).

\subsection{Karakterisasi Senyawa Hasil Sintesis}

Karakterisasi senyawa hasil sintesis dilakukan menggunakan spektroskopi NMR, IR dan MS. Spektroskopi ${ }^{1} \mathrm{H}-\mathrm{NMR}$ dan ${ }^{13} \mathrm{C}$-NMR diukur pada Agilent DD2 dan JEOL ECA $500 \mathrm{MHz}$ dengan pelarut cloroform-d $\left(\mathrm{CDCl}_{3}\right)$. Spektroskopi IR menggunakan spektrometer Alpha Bruker FTIR dan spektroskopi masa (MS) menggunakan (HRESIMS) Waters LCT Premiere XE.

Senyawa vanilil metil keton, padatan berwarna kuning, $493 \mathrm{mg}(45 \%),{ }^{1} \mathrm{H} \mathrm{NMR}\left(500 \mathrm{MHz}, \mathrm{CDCl}_{3}\right): \delta_{\mathrm{H}} 6,88(\mathrm{~d}, J=7,8$ $\mathrm{Hz}, 1 \mathrm{H}), 6,72(\mathrm{~s}, 1 \mathrm{H}), 6,70(\mathrm{~s}, 1 \mathrm{H}), 5,63(\mathrm{~s}, \mathrm{br}, 1 \mathrm{H}), 3,88(\mathrm{~s}, 3 \mathrm{H}), 3,62(\mathrm{~s}, 2 \mathrm{H}), 2,15(\mathrm{~s}, 3 \mathrm{H}) ;{ }^{13} \mathrm{C} \mathrm{NMR}\left(125 \mathrm{MHz}, \mathrm{CDCl}_{3}\right): \delta_{\mathrm{c}}$ $206,99,146,67,144,77,126,01,122,28,114,57,111,63,55,91,50,68,29,04$ ppm; IR (KBr): $v_{\text {maks }} 3435,3002,2934,2838$, $1708,1601,1518,1431,1271,769 \mathrm{~cm}^{-1}$; HRESIMS $\left(\mathrm{C}_{10} \mathrm{H}_{12} \mathrm{O}_{3}\right)$ dengan nilai $(\mathrm{M}-\mathrm{H})$ - data pengukuran $\mathrm{m} / \mathrm{z}$ : 179,0707 dan data perhitungan $\mathrm{m} / \mathrm{z}$ : 179,0708.

Senyawa vanilin, padatan berwarna kuning pucat, $30 \mathrm{mg}(3 \%),{ }^{1} \mathrm{H}$ NMR $\left(500 \mathrm{MHz}, \mathrm{CDCl}_{3}\right): \delta_{\mathrm{H}} 9,83(\mathrm{~s}, 1 \mathrm{H}), 7,44$ (dd, $\left.J_{1}=5 \mathrm{~Hz}, J_{2}=1,7 \mathrm{~Hz}, 1 \mathrm{H}\right), 7,43(\mathrm{~d}, J=1,3 \mathrm{~Hz}, 1 \mathrm{H}), 7,05(\mathrm{~d}, J=8,5 \mathrm{~Hz}, 1 \mathrm{H}), 6,25$ (s, br, 1H), 3,98 (s, 3H); ${ }^{3} \mathrm{C}$ NMR (125 MHz, $\left.\mathrm{CDCl}_{3}\right): \delta_{\mathrm{c}} 190,92,151,71,147,17,129,93,127,57,114,41,108,8,56,16 \mathrm{ppm}$; IR (KBr) : Vmaks 3182, 2941, 2842, 1671, 1587, 1514, 1467, 1428, 1271, 1207, 1153, 1027, 860, 731; HRESIMS $\left(\mathrm{C}_{8} \mathrm{H}_{8} \mathrm{O}_{3}\right)$ dengan nilai $(\mathrm{M}-\mathrm{H})^{+}$data pengukuran $\mathrm{m} / \mathrm{z}: 153,0551$ dan data perhitungan $\mathrm{m} / \mathrm{z}: 153,0552$.

\subsection{Analisis in Silico}

\subsubsection{Persiapan Ligan dari Protein}

Molekul enzim COX-1 dan COX-2 pada manusia diperoleh dari Protein Data Bank (PDB) https://www.rcsb.org dengan kode COX-1 (ID: 5GMM) dan COX-2 (ID: 5GMN). Ligan diperoleh dari bank data https://www.pubchem.com dengan kode vanilil metil keton (CID: 17262) dan eugenol (CID: 3314) yang ditunjukkan pada Gambar 1. Preparasi molekul enzim dan ligan dilakukan menggunakan perangkat lunak Discovery Studio Client 4.1. untuk mengganti ligan menjadi bentuk format PDB dan menghilangkan molekul air yang melekat pada enzim COX-1 dan COX-2. Preparasi selanjutnya dilakukan dengan Autodock 4.2 untuk menambahkan hidrogen polar, muatan dan menyimpan enzim serta ligan dalam format PDBQT. Selain itu, dengan Autodock 4.2 juga dilakukan analisis ukuran grid box yang akan digunakan dalam proses docking.

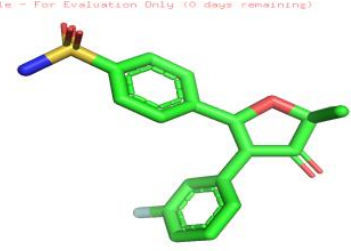

(A)

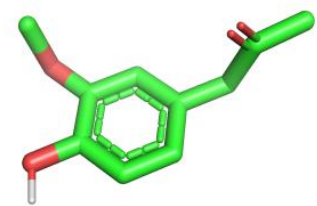

(B)

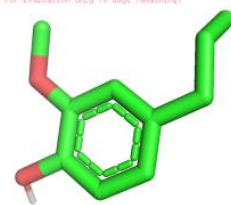

(C)

Gambar 1. Struktur 3D ligan: (A) Ligan natif pada enzim COX-1 dan COX-2, (B) Vanilil metil keton, dan (C) Eugenol

\subsubsection{Validasi Metode Docking Molekuler}

Untuk mengetahui ketepatan posisi ligan dan grid box yang dipakai dalam proses molecular docking, maka dilakukan validasi dengan melakukan redocking antara ligan natif dengan enzim menggunakan Autodock Vina. Hasil redocking kemudian dianalisis menggunakan PyMOL untuk mengetahui nilai root mean square deviation (RMSD) antara ligan natif asal dari PDB dengan ligan natif hasil redocking. Metode molecular docking yang dilakukan dikatakan valid apabila nilai RMSD $\leq 2,0 \AA$ [27].

\subsubsection{Molecular Docking}

Docking molekuler antara ligan dan enzim dilakukan menggunakan Autodock Vina. Hasil docking dianalisis menggunakan PyMOL untuk melihat posisi ligan dalam pocket sisi aktif enzim. Selanjutnya interaksi antara ligan dengan enzim dianalisis menggunakan LigPlot. 


\section{Hasil dan Pembahasan}

\subsection{Sintesis Senyawa Vanilil Metil Keton}

Oksidasi eugenol menjadi vanilil metil keton dilakukan dengan pereaksi Wacker menggunakan katalis paladium klorida 10\% mol (Gambar 2). Selama proses reaksi, $\mathrm{Pd}(\mathrm{II})$ akan mengalami reduksi menjadi $\mathrm{Pd}(0)$ sehingga digunakan ko-oksidan $\mathrm{CuCl}_{2}$ untuk mengoksidasi kembali $\mathrm{Pd}(0)$ menjadi $\mathrm{Pd}(\mathrm{II})$. Mekanisme reaksi oksidasi Wacker (Gambar 3) diawali dengan pengikatan ion $\mathrm{Cl}^{-}$oleh senyawa $\mathrm{PdCl}_{2}$ membentuk $\mathrm{PdCl}_{4}$, kemudian dilanjutkan dengan pergantian atom $\mathrm{Cl}$ dengan senyawa eugenol sehingga menjadi kompleks $\mathrm{PdCl}_{3}$-eugenol. Dengan adanya molekul $\mathrm{H}_{2} \mathrm{O}$, maka atom $\mathrm{Cl}$ yang terikat pada paladium dapat digantikan oleh $\mathrm{H}_{2} \mathrm{O}$ dan selanjutnya akan mengalami reaksi adisi oleh gugus hidroksi dari air [28]. Sesuai dengan aturan Markovnikov, regioselektifitas reaksi adisi dengan air cenderung akan masuk pada karbon yang lebih tersubstitusi yaitu karbon sekunder. Hal ini disebabkan oleh adanya efek hiperkonjugasi yang dapat menstabilkan karbokation. Mekanisme reaksi Wacker diakhiri dengan adanya penataan ulang ikatan membentuk gugus keton [29].

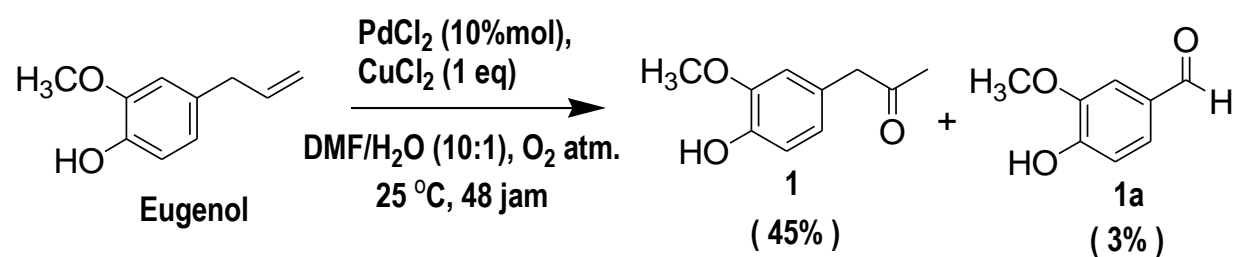

Gambar 2. Oksidasi Wacker pada senyawa eugenol, (1) vanilil metil keton, dan (1a) vanilin.

Senyawa hasil sintesis berupa campuran dua senyawa yang selanjutnya dipisahkan menggunakan kolom kromatografi dengan eluen diklorometana:n-heksana (7:3). Hasil pemisahan diperoleh senyawa 1 (vanilil metil keton) sebanyak $493 \mathrm{mg}$ dengan rendemen sebesar $45 \%$. Uji kemurnian dilakukan dengan kromatografi lapis tipis (KLT) menggunakan tiga sistem eluen yang berbeda yaitu diklorometana dengan $R_{f} 0,43$, n-heksana:etil asetat $(7: 3)$ dengan $R_{f}$ 0,40 dan n-heksana:diklorometana (1:9) dengan $\mathrm{R}_{\mathrm{f}} 0,35$.

\subsection{Identifikasi Senyawa Hasil Sintesis}

Analisis struktur senyawa 1 menggunakan spektroskopi NMR menunjukkan adanya 10 sinyal karbon pada spektrum ${ }^{13} \mathrm{C}$-NMR yaitu satu sinyal karbonil $(\mathrm{C}=0)$, enam sinyal aromatik dan tiga sinyal alifatik. Adanya sinyal karbonil pada pergeseran 206,9 ppm menunjukkan bahwa sinyal tersebut adalah sinyal dari gugus keton yang tidak terkonjugasi [30]. Hal ini membuktikan bahwa terjadi reaksi oksidasi dari olefin menjadi keton. Data tersebut juga diperkuat dengan adanya sinyal metil $\left(\mathrm{CH}_{3}\right)$ dan metilen $\left(\mathrm{CH}_{2}\right)$ pada spektrum ${ }^{1} \mathrm{H}-\mathrm{NMR}$ yang muncul pada pergeseran 2,15 ppm dan 3,62 ppm, dimana metil dan metilen tersebut merupakan alkil yang berikatan dengan gugus karbonil (keton). Pada ${ }^{1} \mathrm{H}-\mathrm{NMR}$ masih terdapat tiga proton aromatik pada pergeseran 6,70-6,88 ppm serta sinyal metoksi yang merupakan substituen pada cincin aromatik muncul sebagai sinyal singlet pada pergeseran 3,88 ppm. Berdasarkan analisis tersebut, maka dapat diasumsikan bahwa senyawa 1 telah berhasil disintesis dari eugenol melalui reaksi oksidasi Wacker. Untuk memperkuat analisis gugus fungsi yang terdapat pada senyawa 1, maka dilakukan pengukuran spektroskopi IR (Gambar 4).

Pada spektrum IR, senyawa 1 memiliki pita serapan pada bilangan gelombang $3435 \mathrm{~cm}^{-1}$ yang merupakan vibrasi ulur dari gugus hidroksi $(\mathrm{OH})$ pada fenol. Adanya gugus keton $(\mathrm{C}=0)$ hasil oksidasi Wacker dibuktikan dengan pita serapan yang muncul secara kuat pada bilangan gelombang $1708 \mathrm{~cm}^{-1}$. Serapan keton tersebut berbeda dengan serapan gugus alkena monosubstitusi pada eugenol yang akan muncul secara lemah pada bilangan gelombang 1648 $\mathrm{cm}^{-1}$ [31]. Serapan $(\mathrm{C}=\mathrm{C})$ aromatik muncul pada bilangan gelombang 1601, 1518, dan $1431 \mathrm{~cm}^{-1}$ sedangkan gugus aril alkil eter $\left(\mathrm{C}-\mathrm{O}-\mathrm{CH}_{3}\right)$ muncul pada bilangan gelombang $1271 \mathrm{~cm}^{-1}$. Pita serapan $\mathrm{C}-\mathrm{H} s p^{2}$ aromatik muncul pada bilangan gelombang $3002 \mathrm{~cm}^{-1}$ dan C-H sp muncul pada bilangan gelombang $2934-2838 \mathrm{~cm}^{-1}$.

Senyawa hasil samping oksidasi Wacker dari senyawa eugenol dihasilkan senyawa 1a sebanyak $3 \%$. Hasil analisis senyawa 1a dengan spektroskopi NMR diperoleh delapan sinyal karbon pada ${ }^{13} \mathrm{C}-\mathrm{NMR}$ yaitu satu sinyal karbonil, enam sinyal aromatik dan satu sinyal alifatik. Berdasarkan jumlah atom karbonnya, dapat diidentifikasi bahwa terdapat pemutusan dua atom karbon pada eugenol menjadi senyawa 1a. Sinyal karbonil pada senyawa 1a muncul pada pergeseran 190,92 ppm, dimana sinyal tersebut merupakan sinyal dari gugus aldehid yang diperkuat dengan adanya sinyal proton aldehid yang muncul pada pergeseran $9,83 \mathrm{ppm}$. Tiga sinyal proton aromatik dan satu sinyal dari substituen metoksi masih muncul pada spektrum ${ }^{1} \mathrm{H}-\mathrm{NMR}$ seperti pada senyawa 1 . Akan tetapi, sinyal proton aromatik pada senyawa 1a memiliki pergeseran sinyal yang lebih deshielding dibandingkan dengan senyawa 1. Hal ini disebabkan karena adanya pengaruh dari gugus aldehid yang merupakan gugus penarik elektron sehingga proton pada posisi orto 
dan para terhadap gugus aldehid tersebut memiliki kerapatan elektron yang lebih kecil [32]. Berdasarkan analisis tersebut, maka dapat disimpulkan bahwa senyawa $1 \mathrm{a}$ adalah senyawa vanilin.

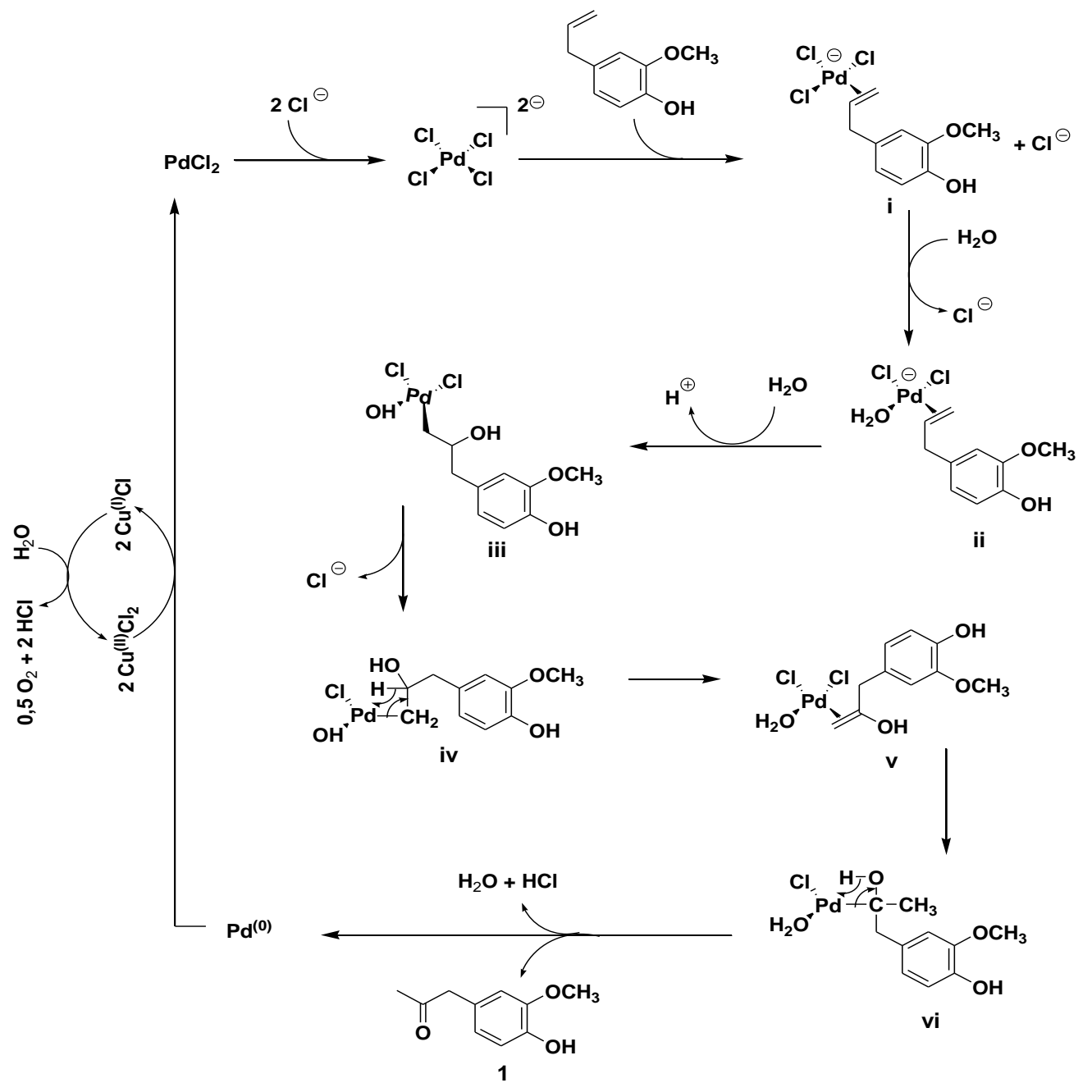

Gambar 3. Mekanisme reaksi oksidasi Wacker pada senyawa eugenol.

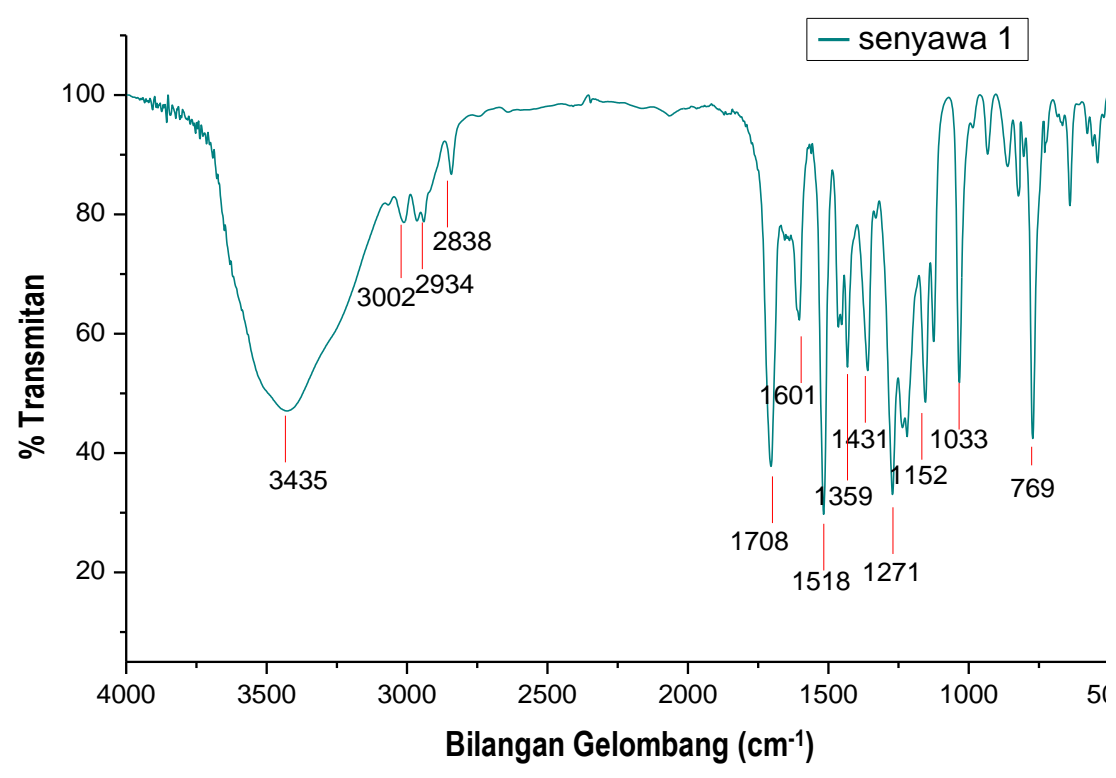

Gambar 4. Spektrum IR senyawa 1. 


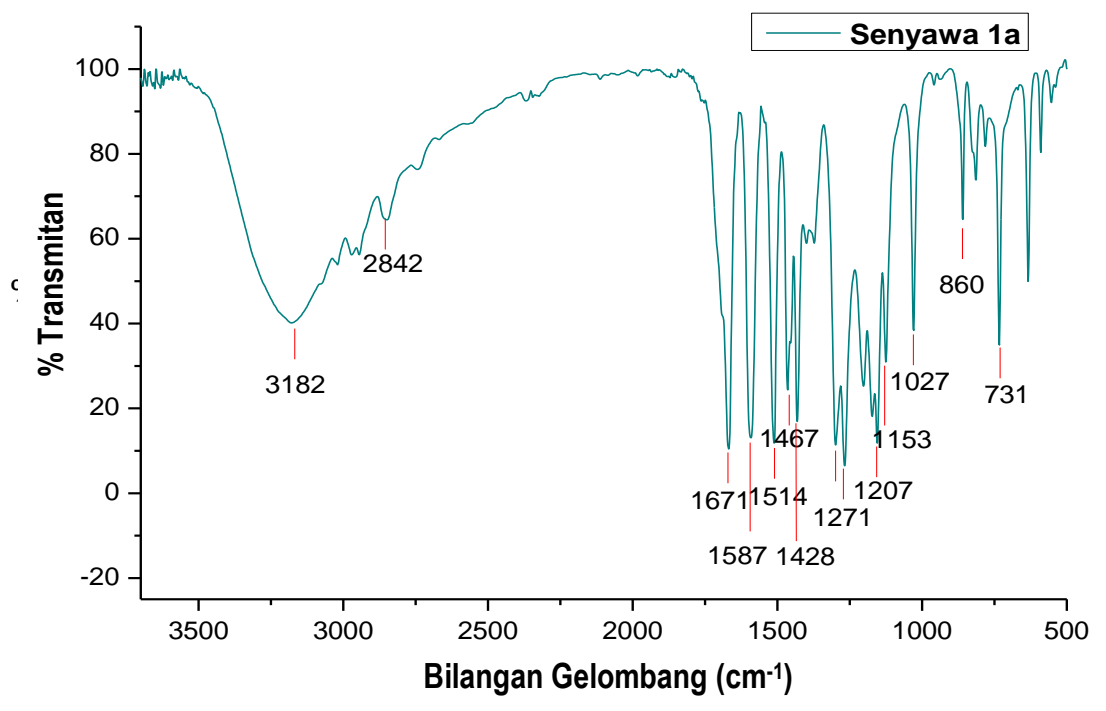

Gambar 5. Spektrum IR senyawa 1a.

Untuk memperkuat hasil analisis NMR senyawa 1a, dilakukan pula identifikasi gugus fungsi menggunakan spektroksopi IR (Gambar 5). Beberapa pita serapan gugus fungsi yang muncul pada senyawa 1a identik dengan senyawa 1 yaitu terdapat gugus fenol yang muncul pada bilangan gelombang $3182 \mathrm{~cm}^{-1},(C=C)$ aromatik pada bilangan gelombang 1587, 1514, dan $1467 \mathrm{~cm}^{-1}$ serta gugus eter pada substituen metoksi $\left(\mathrm{C}-\mathrm{O}-\mathrm{CH}_{3}\right)$ yang muncul pada bilangan gelombang $1271 \mathrm{~cm}^{-1}$. Terdapat pita serapan gugus karbonil yang muncul secara kuat pada bilangan gelombang 1671 $\mathrm{cm}^{-1}$, dimana nilai bilangan gelombang tersebut lebih rendah dari pada gugus keton pada senyawa 1 . Serapan karbonil pada senyawa 1a tersebut diidentifikasi sebagai gugus aldehid $(\mathrm{HC}=0)$ yang terkonjugasi dengan aromatik [31]. Hasil analisis IR tersebut memperkuat analisis spektroskopi NMR bahwa senyawa 1a merupakan senyawa vanilin. Terbentuknya senyawa vanilin pada oksidasi Wacker disebabkan karena terjadi isomerisasi alil benzena pada eugenol menjadi propenilbenzena yang diikuti dengan pemutusan secara oksidatif pada ikatan olefiniknya. Reaksi pemutusan ikatan olefin tersebut kemungkinan terjadi melalui proses mekanisme auto-oksidasi radikal [33].

\subsection{Analisis in Silico}

\subsubsection{Validasi Metode Docking}

Validasi metode docking dilakukan untuk mengetahui ketepatan posisi ligan dan grid box yang akan dipakai dalam proses docking molekuler [5]. Sebelum proses validasi, dilakukan preparasi dengan memisahkan struktur enzim COX-1 dan COX-2 dengan ligan natif menggunakan Autodock 4.2. Sruktur enzim yang digunakan adalah rantai A dengan ligan natif inhibitornya adalah 4-[3-(3-fluorophenyl)-5,5-dimethyl-4-oxidanylidene-furan-2-yl]benzenesulfonamide. Pada proses preparasi dilakukan pula analisis terhadap kompleks enzim dan ligan natif menggunakan LigPlot untuk menentukan residu aktif yang terlibat pada interaksi kompleks enzim-ligan. Residu aktif tersebut digunakan sebagai pertimbangan dalam penentuan ukuran grid box, dimana ukuran grid box yang digunakan harus meliputi semua residu aktif yang terlibat dalam interaksi 45 pada sisi aktif enzim [34]. Hasil pengukuran grid box menggunakan Autodock 4.2 pada enzim COX-1

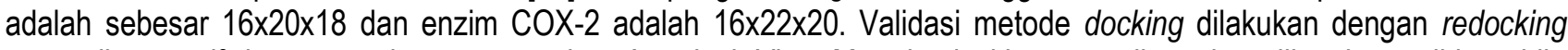
antara ligan natif dengan enzim menggunakan Autodock Vina. Metode docking yang digunakan dikatakan valid apabila nilai RMSD $\leq 2,0 \AA$ [27]. Hasil validasi redocking pada enzim COX-1 dan COX-2 (Gambar 6) terlihat bahwa ligan natif hasil redocking telah berhimpit dengah ligan natif dari PDB dengan nilai RMSD sebesar 1,589 ^ pada COX-1 dan sebesar $0,923 \AA$ pada COX-2. Hal ini menunjukkan bahwa ukuran grid box yang digunakan pada validasi docking ini telah benar dan dapat digunakan untuk proses docking senyawa hasil sintesis [27].

\subsubsection{Docking Molekuler}

Docking molekuler senyawa hasil sintesis (vanilil metil keton) dilakukan menggunakan Autodock Vina kemudian dianalisis menggunakan PyMOL dan LigPlot. Potensial aktivitas antiinflamasi yang diperoleh melalui docking molekuler dapat dilihat dari nilai afinitas energi pengikatan dan jumlah interaksi yang terjadi antara ligan dengan sisi aktif enzim (Gambar 7). Afinitas energi ikatan enzim-ligan merupakan energi yang dibutuhkan untuk membentuk ikatan antara ligan dengan enzim. Semakin kecil energi yang dibutuhkan maka semakin stabil kompleks enzim-ligan tersebut [34]. Jumlah interaksi yang terjadi antara ligan dengan sisi aktif enzim seperti ikatan hidrogen dan interaksi hidrofobik juga mempengaruhi aktivitasnya. Banyaknya ikatan hidrogen yang terbentuk pada interaksi protein-ligan memberikan 
kontribusi terhadap kestabilan struktur kompleks, dengan kata lain semakin banyak jumlah ikatan hidrogen yang terbentuk maka akan semakin kompleks strukturnya [27]. Dalam interaksi protein-ligan, ikatan hidrogen dan ikatan hidrofobik juga mempengaruhi stabilitas ikatan antara ligan dan targetnya. Bila ikatan hidrogen yang cukup banyak disertai dengan interaksi hidrofobik, maka dapat dikatakan bahwa interaksi antara kedua molekul tersebut merupakan interaksi yang cukup kuat [35].

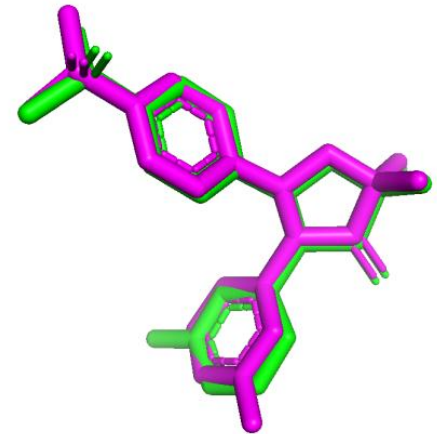

(A)

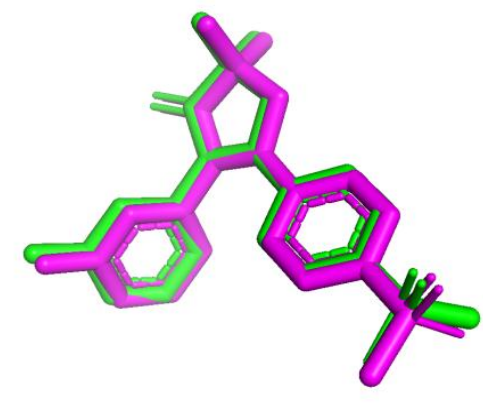

(B)

Gambar 6. Hasil validasi ligan natif pada enzim COX-1 (A) dan COX-2 (B). Ligan dari PDB ditunjukkan dengan warna hijau, sedangkan ligan hasil redocking ditunjukkan warna ungu.

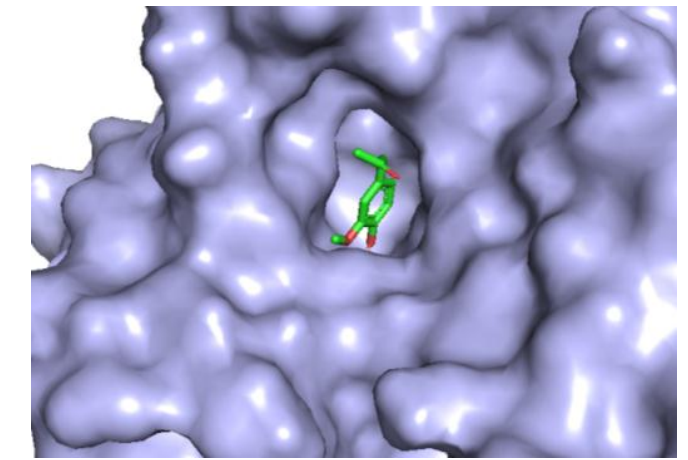

(A)

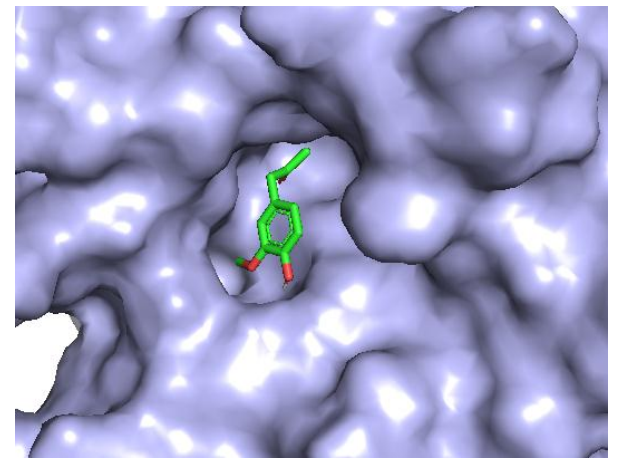

(B)

Gambar 7. Posisi senyawa vanilil metil keton pada sisi aktif enzim: (A) COX-1 dan (B) COX-2.

Hasil simulasi docking molekuler (Gambar 8) menunjukkan bahwa senyawa 1 (vanilil metil keton) dapat berinteraksi dengan sisi aktif enzim COX-1 melalui 4 ikatan, hidrogen yaitu antara gugus keton pada senyawa 1 dengan hidrogen pada Gln92 dengan jarak ikatan sebesar 2,90 Á dan oksigen pada gugus metoksi berikatan hidrogen dengan Thr199 (2,99 Á). Gugus hidroksi $(\mathrm{OH})$ pada senyawa 1 dapat berikatan hidrogen dengan dua residu asam amino pada sisi aktif enzim. Atom oksigen pada gugus hidroksi berikatan hidrogen dengan His119 (3,04 Á) sedangkan atom hidrogennya berikatan dengan atom oksigen pada gugus hidroksi Thr 199 (2,77 Á). Kompleks tersebut juga distabilkan dengan adanya interaksi hidrofobik antara senyawa 1 dengan residu Val43, Phe91, His94, Ala121, His200 dan Trp209 pada sisi aktif enzim COX-1. Kestabilan kompleks enzim-ligan diperkuat dengan nilai afinitas energi pengikatan yang rendah yaitu sebesar $-5,9 \mathrm{kkal} / \mathrm{mol}$ (Tabel.1). Berdasarkan jumlah interaksi antara senyawa 1 dengan enzim COX-1, maka dapat dikatakan bahwa senyawa 1 memiliki aktivitas inhibisi yang lebih tinggi jika dibandingkan dengan eugenol, dimana pada senyawa eugenol hanya gugus hidroksi yang dapat berikatan hidrogen dengan sisi aktif enzim (Gambar 8). Atom oksigen pada gugus hidroksi eugenol berikatan hidrogen dengan 2 asam amino yaitu His96 (3,06 Å) dan His119 (3,34 Å), sedangkan atom hidrogennya berikatan dengan atom oksigen pada gugus hidroksi asam amino Thr199 (2,82 A). Berdasarkan data tersebut juga terlihat bahwa adanya gugus keton pada senyawa 1 berkontribusi dalam interaksi enzimligan melalui ikatan hidrogen. Dengan kata lain, keberadaan gugus keton pada senyawa 1 dapat meningkatkan kestabilan kompleks enzim-ligan sehingga dapat meningkatkan aktivitas inhibisi terhadap enzim COX-1 [21].

Gugus keton pada senyawa 1 (vanilil metil keton) juga berperan penting dalam interaksinya dengan sisi aktif enzim COX-2. Pada Gambar 8 terlihat bahwa gugus keton pada senyawa 1 dapat berikatan hidrogen dengan 3 asam amino yaitu His94 (3,10 Á), His96 (3,18 Á), dan His119 (3,01 Á). Selain gugus keton, gugus metoksi pada senyawa 1 juga dapat berikatan hidrogen dengan 2 residu asam amino, Asn67 (3,01 Á) dan $\operatorname{Gn} 92(2,98 \AA)$, serta diperkuat dengan beberapa interaksi hidrofobik dengan asam amino His64, Ala65, Thr198, Thr199 dan Trp208 (Tabel 1). Seperti halnya pada inhibisi enzim COX-1, aktivitas inhibisi senyawa 1 terhadap COX-2 juga lebih tinggi dibandingkan eugenol yang dibuktikan dengan jumlah ikatan hidrogen pada senyawa 1 lebih banyak dari pada eugenol. Eugenol hanya memiliki dua ikatan 
hidrogen melalui atom oksigen pada gugus hidroksi $(\mathrm{OH})$ dengan atom hidrogen pada residu asam amino His96 (3,23 $⿱$ ) dan His119 (3,11 Å). Dalam hal ini, adanya gugus keton pada senyawa 1 berkontribusi dalam peningkatan kompleksitas enzim-ligan, begitu pula dengan aktivitas inhibisi terhadap enzim COX-2. Tingginya potensial inhibisi senyawa 1 terhadap COX-2 juga didukung dengan nilai afinitas energi pengikatan yang lebih rendah dibandingkan dengan eugenol yaitu sebesar -6,2 kkal/mol (Tabel 1).

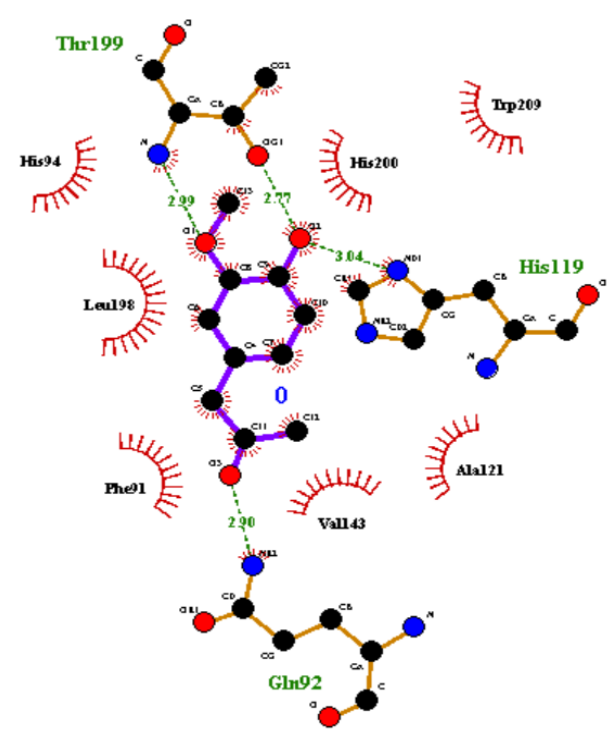

(a) Interaksi senyawa 1 dengan enzim COX-1

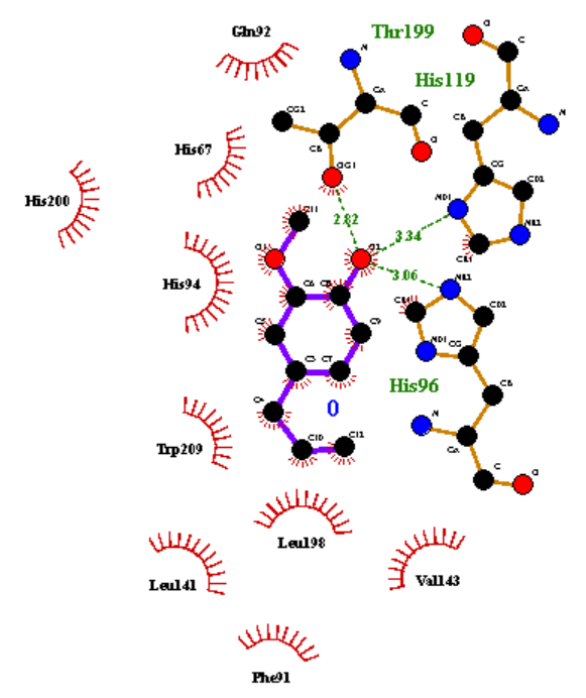

(c) Interaksi eugenol dengan enzim COX-1

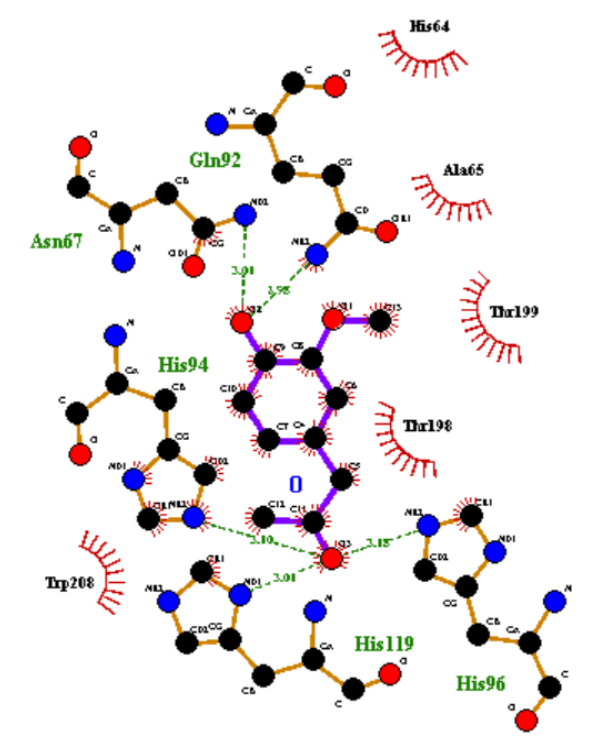

(b) Interaksi senyawa 1 dengan enzim COX-2

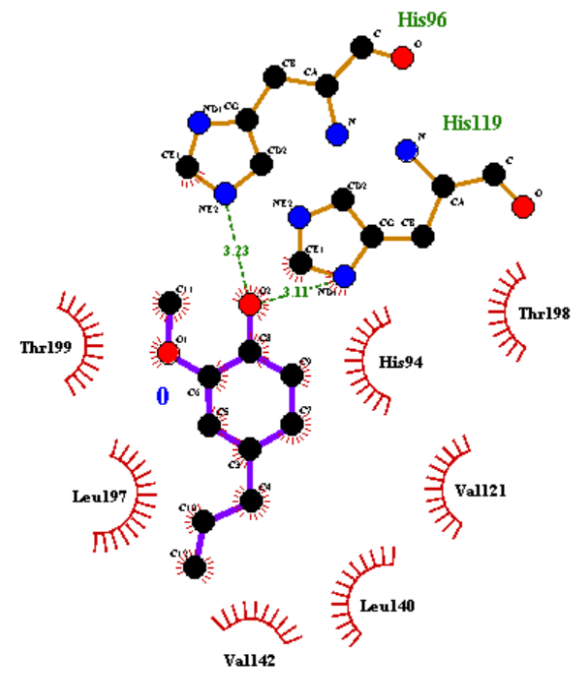

(d) Interaksi eugenol dengan enzim COX-2

Gambar 8. Interaksi senyawa ligan dengan enzim COX-1 dan COX-2.

Secara keseluruhan hasil docking molekuler senyawa 1 terhadap enzim COX-1 dan COX-2 menunjukkan bahwa keberadaan gugus keton pada senyawa 1 dapat meningkatkan aktivitas inhibitornya melalui ikatan hidrogen dengan sisi aktif enzim. Oleh karena itu, potensial inhibisi senyawa 1 terhadap kedua enzim tersebut lebih tinggi dibandingkan dengan eugenol, begitu pula aktivitas antiinflamasinya. Berdasarkan perbandingan hasil inhibisi senyawa 1 terhadap COX-1 dan COX-2, terlihat bahwa senyawa vanilil metil keton juga memiliki selektivitas inhibitor yang lebih tinggi terhadap enzim COX-2 dibandingkan COX-1. Selektivitas tersebut dibuktikan dengan nilai afinitas energi pengikatan pada enzim COX-2 yang lebih rendah dari pada COX-1. Hal tersebut juga diperkuat dengan jumlah ikatan hidrogen antara senyawa 1 dengan sisi aktif enzim COX-2 lebih banyak dibandingkan COX-1 (Gambar 5). Dengan demikian dapat disimpulkan bahwa transformasi gugus olefin pada senyawa eugenol menjadi gugus keton (vanilil metil keton) dapat meningkatkan aktivitasnya sebagai antiinflamasi serta selektivitas inhibisinya terhadap enzim COX-2. 
Tabel 1. Hasil Docking Senyawa Eugenol dan Vanilil Metil Keton

\begin{tabular}{|c|c|c|c|c|}
\hline \multirow{2}{*}{$\begin{array}{c}\text { Enzim } \\
\text { Senyawa }\end{array}$} & \multicolumn{2}{|c|}{ COX-1 } & \multicolumn{2}{|c|}{ COX-2 } \\
\hline & Eugenol & Vanilil metil keton & Eugenol & Vanilil metil keton \\
\hline Energi (kkal/mol) & $-5,9$ & $-5,9$ & $-5,7$ & $-6,2$ \\
\hline Ikatan hidrogen & $\begin{array}{l}\text { His96 (3,06 Å), } \\
\text { His119 (3,34 Å), } \\
\text { Thr199 (2,82 Á) }\end{array}$ & 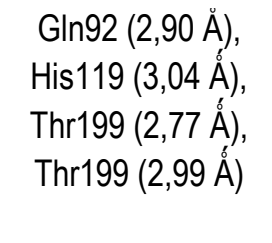 & $\begin{array}{l}\text { His96 }(3,23 \AA) \\
\text { His119 }(3,11 \AA \AA)\end{array}$ & 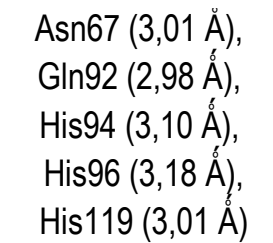 \\
\hline Interaksi hidrofobik & $\begin{array}{l}\text { Leu41, Val43, } \\
\text { His67, Phe91, } \\
\text { GIn92, His94, } \\
\text { Leu198, His200, } \\
\text { Trp209 }\end{array}$ & $\begin{array}{l}\text { Val43, Phe91, } \\
\text { His94, Ala121, } \\
\text { His200, Trp209 }\end{array}$ & $\begin{array}{c}\text { Val42, His94, } \\
\text { Val121, Leu140, } \\
\text { Leu197, Thr198, } \\
\text { Thr199 }\end{array}$ & $\begin{array}{l}\text { His64, Ala65, } \\
\text { Thr198, Thr199, } \\
\text { Trp208 }\end{array}$ \\
\hline
\end{tabular}

\section{Kesimpulan}

Oksidasi Wacker pada senyawa eugenol menghasilkan senyawa vanilil metil keton dengan randemen $45 \%$ dan produk samping berupa vanillin sebanyak $3 \%$. Berdasarkan analisis in silico, senyawa vanilil metil keton memiliki aktivitas antiinflamasi yang lebih tinggi dibandingkan dengan eugenol dan memiliki selektivitas yang lebih tinggi terhadap enzim COX-2 dibandingkan COX-1. Hal ini ditunjukkan melalui rendahnya afinitas energi pengikatan dan banyaknya ikatan hidrogen yang terbentuk antara vanilil metil keton dengan sisi aktif enzim. Analisis lebih lanjut melalui uji in vitro dan in vivo sangat dibutuhkan untuk validasi hasil analisis in silico.

\section{Daftar Pustaka}

[1] P. G. Conaghan, "A Turbulent Decade for NSAIDs: Update on Current Concepts of Classification, Epidemiology, Comparative Efficacy, and Toxicity", Rheumatology International, vol. 32, no. 6, pp. 1491-502, 2012.

[2] J. A. Mitchell, S. Larkin, \& T. J. Williams, "Cyclooxygenase-2: Regulation and Relevance in Inflammation", Biochemical Pharmacology, vol. 50, no. 10, pp. 1535-1542, 1995.

[3] A. A. M. Abdel-Aziz, A. Angeli, A. S. El-Azab, M. E. A. Hammouda, M. A. El-Sherbeny, \& C. T. Supuran, "Synthesis and Anti-inflammatory Activity of Sulfonamides and Carboxylates Incorporating Trimellitimides: Dual Cyclooxygenase/Carbonic Anhydrase Inhibitory Actions", Bioorganic Chemistry, vol. 84, pp. 260-268, 2019.

[4] P. P. Kapupara, S. P. Dholakia, V. P. Patel, \& B. N. Suhagia, "Design, Synthesis and Pharmacological Screening of 4-Amino-5-pyrimidinecarbonitriles as Potential Anti-inflammatory Agents", Journal of Chemical and Pharmaceutical Research, vol. 2, no. 3, pp. 287-294, 2010.

[5] R. D. Kamble, R. J. Meshram, S. V. Hese, R. A. More, S. S. Kamble, R. N. Gacche, \& B. S. Dawane, "Synthesis and In Silico Investigation of Thiazoles Bearing Pyrazoles Derivatives as Anti-Inflammatory Agents" Computational Biology and Chemistry, vol. 61, pp. 86-96, 2016.

[6] R. Ottana, R. Maccari, M. L. Barreca, G. Bruno, A. Rotondo, A. Rossi, G. Chiricosta, R. Di Paola, L. Sautebin, S. Cuzzocread, \& M. G. Vigorita, "5-Arylidene-2-imino-4-thiazolidinones: Design and Synthesis of Novel Antiinflammatory Agents", Bioorganic and Medical Chemistry, vol. 13, no. 13, pp. 4243-4252, 2005.

[7] S. Bindu, S. Mazumder, \& U. Bandyopadhyay, "Non-steroidal Anti-inflammatory Drugs (NSAIDs) and Organ Damage: A Current Perspective", Biochemical Pharmacology, vol.180, no. 114147, 2020.

[8] P. Apridamayanti, F. Sanera, \& Robiyanto, "Aktivitas Antiinflamasi Ekstrak Etanol Daun Karas (Aquilaria malaccensis Lamk.)", Pharmaceutical Sciences and Research, vol. 5, no. 3, pp. 152-158, 2018.

[9] O. K. Nwosu, M. Keskin, H. Lohani, C. Egbuna, \& S. Z. Haider, "Bioactive Lead Compounds and Molecular the Development of Antiinflammatory Drugs", Phytochemicals as Lead Compounds for New Drug Discovery, pp. 317331, 2020.

[10] J.-H Lee, H.-H. Lee, K.-N. Kim, \& K.-M. Kim, "Cytotoxicity and Anti-inflammatory Effects of Zinc lons and Eugenol during Setting of ZOE in Immortalized Human Oral Keratinocytes Grown as Three-dimensional Spheroids", Dental Materials, vol. 32, no. 5, pp. e93-e104, 2016. 
[11] X. Huang, Y. Liu, Y. Lu, \& C. Ma, "Anti-inflammatory Effects of Eugenol on Lipopolysaccharide-induced Inflammatory Reaction in Acute Lung Injury via Regulating Inflammation and Redox Status", International Immunopharmacology, vol. 26, no. 1, pp. 265-271, 2015.

[12] H. Prianto, R. Retnowati, \& U. P. Juswono, "Isolasi dan Karakterisasi dari Minyak Bunga Cengkeh (Syzigium aromaticum) Kering Hasil Distilasi Uap", Jurnal Ilmu Kimia Universitas Brawijaya, vol. 1, no. 2, pp. 269-275, 2013.

[13] T. S. Kaufman, "The Multiple Faces of Eugenol. A Versatile Starting Material and Building Block for Organic and Bio-organic Synthesis and a Convenient Precursor toward Bio-based Fine Chemicals", Journal of the Brazilian Chemical Society, vol. 26, no. 6, pp. 1055-1085, 2015.

[14] W. Qian, Z. Sun, T. Wang, M. Yang, M. Liu, M., J. Zhang, \& Y. Li "Antimicrobial Activity of Eugenol against Carbapenem-resistant Klebsiella pneumoniae and Its Effect on Biofilms", Microbial Pathogenesis, vol. 139, 2020.

[15] J. Bonilla, T. Poloni, R. V. Lourenço, \& P. J. A. Sobral, "Antioxidant Potential of Eugenol and Ginger Essential Oils with Gelatin/Chitosan Films, Food Bioscience, vol. 23, pp. 107-114, 2018.

[16] J. Towaha, "The Benefits of Cloves Eugenol in Various Industries in Indonesia", Majalah Perspektif Review Penelitian Tanaman Industri, vol. 11, no. 2, pp. 79-90, 2012.

[17] W. Wibowo, W. P. Suwarso, T. Utari, \& H. Purwaningsih, "Aplikasi Reaksi Katalisis Heterogen untuk Pembuatan Vanilin Sintetik (3-hidroksi-2-metoksibenzaldehid) dari Eugenol (4-alil-2-metoksifenol) Minyak Cengkeh", Makara Sains, vol. 6, no. 3, pp. 142-148, 2002.

[18] D. Deffieux, P. Gossart, \& S. Quideau, "Facile and Sustainable Synthesis of the Natural Antioxidant Hydroxytyrosol", Tetrahedron Letters, vol. 55, no. 15, pp. 2455-2458, 2014.

[19] B. G. Harvey, A. J. Guenthner, G. R. Yandek, L. R. Cambrea, H. A. Meylemans, L. C. Baldwin, \& J. T. Reams, "Synthesis and Characterization of a Renewable Cyanate Ester/Polycarbonate Network Derived from Eugenol", Polymer, vol. 55, no.20, pp. 5073-5079, 2014.

[20] R. Heiran, S. Sepehri, A. Jarrahpour, C. Digiorgio, H. Douafer, J. M. Brunel, A. Gholami, E. Riazimontazer, \& E. Turos, "Synthesis, Docking and Evaluation of in Vitro Anti-inflammatory Activity of Novel Morpholine Capped $\beta$ Lactam Derivatives", Bioorganic Chemistry, vol. 102, 2020.

[21] L. Arshad, M. A. Haque, S. N. A. Bukhari, \& I. Jantan, "An Overview of Structure-activity Relationship Studies of Curcumin Analogs as Antioxidant and Anti-inflammatory agents, Future Medicinal Chemistry, vol. 9, no. 6. 605-626, 2017.

[22] J. R. McCombs, B. W. Michel, \& M. S. Sigman, "Catalyst-controlled Wacker-type Oxidation of Homoallylic Alcohols in the Absence of Protecting Groups", Journal of Organic Chemistry, vol. 76, no. 9, pp. 3609-3613, 2011.

[23] J. M. Takacs, \& X. Jiang, "The Wacker Reaction and Related Alkene Oxidation Reactions", Current Organic Chemistry, vol. 7, no. 4, pp. 369-396, 2003.

[24] T. Mitsudome, T. Umetani, K. Mori, T. Mizugaki, K. Ebitani, \& K. Kaneda, "Highly Efficient Wacker Oxidation Catalyzed by Heterogeneous Pd Montmorillonite under Acid-free Conditions", Tetrahedron Letters, vol. 47, no. 9, pp. 1425-1428, 2006.

[25] H. R. Darabi, M. Mirzakhani, K. Aghapoor, K. Jadidi, L. Faraji, \& N. Sakhaee, "A Structure-activity Relationship Study on the Wacker Oxidation of Stilbenes at Ambient Condition", Journal of Organometallic Chemistry, vol. 740, pp. 131-134, 2013.

[26] M. Cox \& G. Klass, "Synthesis By-products from the Wacker Oxidation of Safrole in Methanol using $\rho$ Benzoquinone and Palladium Chloride", Forensic Science International, vol. 164, no.2-3, pp. 138-147, 2006.

[27] W. F. de Azevedo Jr., Docking Screens for Drug Discovery. New York: Humana Press, 2019.

[28] H. Eshtiagh-Hosseini, S. A. Beyramabadi, A. Morsali, \& M. R. Housaindokht, "O-H Bond Cleavage Step of the Wacker Process: A DFT study", Journal of Molecular Structure THEOCHEM, vol. 941, no. 1, pp. 138-143, 2010.

[29] T. V. Baiju, E. Gravel, E. Doris, \& I. N. N. Namboothiri, "Recent Developments in Tsuji-Wacker Oxidation", Tetrahedron Letters, vol. 57, no. 36, pp. 3993-4000, 2016.

[30] P. Y. Bruice, Organic Chemistry, $4^{\text {th }}$ Ed. New York: Prentice Hall, 2003.

[31] R. M. Silverstein, F. X. Webster, \& D. J. Kiemle, Spectrometric Identification of Organic Compounds, $7^{\text {th }}$ Ed. New York: John Wiley and Sons, Inc., 2005.

[32] D. L. Pavia, G. M. Lampman, G. S. Kriz, \& J. R. Vyvyan, Introduction to Spectroscopy, $4^{\text {th }}$ Ed. California: Brooks/Cole, 2009.

[33] L. A. Parreira, L. Menini, J. C. da Cruz Santos, \& E. V. Gusevskaya, "Palladium-catalyzed Aerobic Oxidation of Naturally Occurring Allylbenzenes as a Route to Valuable Fragrance and Pharmaceutical Compounds", Advanced Synthesis and Catalysis, vol. 352, no.9, pp. 1533-1538, 2010. 
[34] T. Joshi, P. Sharma, T. Joshi \& S. Chandra, "In Silico Screening of Anti-inflammatory Compounds from Lichen by Targeting Cyclooxygenase-2", Journal of Biomolecular Structure and Dynamics, vol. 38, no. 12, pp. 3544-3562, 2019.

[35] R. Patil, S. Das, A. Stanley, L. Yadav, A. Sudhakar, \& A. K. Varma, "Optimized Hydrophobic Interactions and Hydrogen Bonding at the Target-Ligand Interface Leads the Pathways of Drug-Designing", Plos One, vol. 5, no. 8, pp. e12029, 2010. 